\title{
ALAT PENGHITUNG BERAT BADAN MANUSIA DENGAN STANDART BODY MASS INDEX (BMI) MENGGUNAKAN SENSOR LOAD CELL BERBASIS ARDUINO MEGA $2560 \mathrm{R3}$
}

\author{
Dewantara, Priyo Sasmoko \\ Program Studi Diploma III Teknik Elektro \\ Fakultas Teknik Universitas Diponegoro \\ Email : dewantara1111@gmail.com
}

\begin{abstract}
Dewantara, Priyo Sasmoko, in this paper explain that a measuring instrument is a tool used by humans to help determine parameters such as height and weight. Most height and weight gauges used today still use simple and still conventional equipment. In addition, if manually, there are still frequent measurement errors that come from the measuring instrument itself or from the human. This happens because of inaccuracies in reading measuring instruments that lack precision or perhaps from the human factor itself. The purpose of this study was to create a digital height and weight automation system accompanied by displaying its ideal weight based on height. This system is built using Arduino as a system controller. The ultrasonic sensor is used as a measure of height. Load cell is used as a measure of weight. And a 20x4 LCD to display the output. From testing and analyzing the results of measurements of height according to the actual height, the results of measurements of weight have an error percentage of $0.53 \%-2.77 \%$. The system determines the ideal or not body weight based on BMI.
\end{abstract}

Keywords: 20x4 LCD, Load Cell Sensor, Arduino.

\section{PENDAHULUAN \\ Latar Belakang}

Pemeliharaan kesehatan adalah upaya penanggulangan dan pencegahan gangguan kesehatan. Salah satu dari sekian banyak yang menyebabkan kesehatan terganggu adalah masalah obesitas atau kegemukan, dan masalah obesitas merupakan hal yang paling banyak terdapat dikalangan masyarakat.

Dalam pembahasannya obesitas didefinisikan sebagai terdapatnya penumpukan lemak yang berlebihan didalam tubuh. Seseorang dianggap menderita kegemukan (obesitas) bila Body Mass Indeks (BMI), yaitu ukuran yang diperoleh dari hasil pembagian berat badan dalam kilogram dengan kuadrat tinggi badan dalam meter, lebih dari 25 $\mathrm{kg} / \mathrm{m} 2$.

Permasalahan kesehatan yang semakin kompleks turut pula menunjang perkembangan teknologi medis. Instrumentasi medis merupakan pengaplikasian dari teknik elektronika, mesin, informasi, dan teknik pengukuran dalam upaya membangun sebuah piranti yang akan dipergunakan untuk melakukan proses monitoring pasien, diagnosa, dan penanganan sebuah penyakit.

Untuk menindak lanjuti hal di atas, perlu melakukan satu penelitian untuk merancang dan membuat alat pengukur indeks massa tubuh dengan menggunakan sensor Load cell sebagai sensor pada timbangan untuk mengukur berat badan, dan sensor ultrasonik sebagai pengukur tinggi badan.

Rumusan masalah dalam peneltian ini adalah bagaimana merancang dan membuat alat penghitung berat badan yang disertai keterangan ideal atau tidaknya seseorang berdasarkan standar Body Mass Index (BMI). Penelitian ini dibatasi pada : sensor massa menggunakan timbangan digital yang dimodifikasi dalam hal ini mengambil output langsung dari load cell yang diubah oleh modul HX711 untuk menampilkan masa tubuh pada LCD.

\section{Permasalahan}

Per masalahan dalam penelitian mengenai alat penghitung berat badan manusia dengan standar BMI ini adalah :

- Arduino sebagai mikrokontroler alat penghitung berat badan

- Sensor load cell sebagai sensor berat

- Body Mass Index sebagai standar untuk menentukan berat ideal.

- Catu daya 9 V sebagai supply dari alat.

\section{CATU DAYA}

Catu Daya atau power supply yang digunakan pada alat ini ada dua macam yaitu baterai Ultrafire 3,7 $\mathrm{V}$ dua buah yang dirangkai secara seri, dan menggunakan rangkaian Catu daya yang menggunakan Transformator step down.

Catu daya adalah suatu rangkaian yang berfungsi sebagai sumber daya untuk mengoperasikan rangkaian yang lain. Jenis rangkaian catu daya cukup banyak tetapi untuk rangkaian yang sederhana biasanya terdiri dari Transformator, penyearah, filter, dan regulator. Prinsip dasar untuk memperoleh tegangan searah dapat dijelaskan dalam diagram blok sebagai berikut pada gambar 1 . 
DIAGRAMBLOK DCPOWER SUPPIY (ADAPTOR)

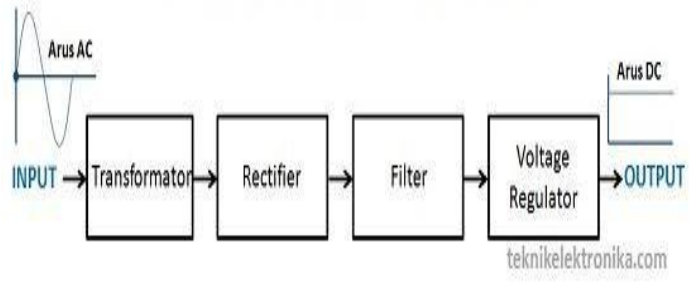

Gambar 1. Diagram Blok Catu Daya

Tegangan AC 220 Volt diturunkan tegangannya menggunakan trafo step down. Setelah itu tegangan disearahkan menggunakan penyearah tegangan atau dioda. Tegangan yang telah disearahkan tadi disaring melalui filter/kapasitor untuk meratakan ripple yang terjadi pada arus agar halus. Tegangan yang halus lalu diregulasi oleh regulator untuk menyesuaikan tegangan yang akan dituju / beban yang dituju, kemudian masuk ke filter lagi agar semakin halus.

\section{LOAD CELL}

\section{Definisi Load Cell}

Load cell adalah alat yang mengeluarkan signal listrik proporsional dengan gaya / beban yang diterimanya. Load cell banyak digunakan pada timbangan elektronik. Kita bisa menyusun load cell dengan metode Strain Gauge dan Jembatan Wheatstone. Dengan menggunakan sebuah kolom baja persegi, kita lekatkan Strain Gauge pada keempat sisinya. Panjang kolom akan berkurang ketika di sisi atas kolom diberikan beban.

Kolom baja juga menjadi "gendut" atau gembung. Dua Strain Gauge yang terpasang berbalikan akan memberikan respon pada perubahan panjang kolom secara proporsional. Dua Strain Gauge yang terletak di sisi yang lain merespon perubahan kolom saat mengalami keadaan "gendut/gembung". Panjang pada sepasang Strain Gauge memendek, diameter kawatnya membesar dan hambatannya berkurang. Sementara sepasang yang lain jadi memanjang, diameter kawatnya mengecil dan hambatannya bertambah. Jika posisi beban digantung pada bagian bawah kolom, kolom akan mengalami gaya tarik. Kolom dan Strain gauge akan merespon kebalikan dari respon diatas tetapi Strain Gauge tetap memanjang dan memendek dengan respon yang sama. Load cell ditunjukkan pada gambar 2.

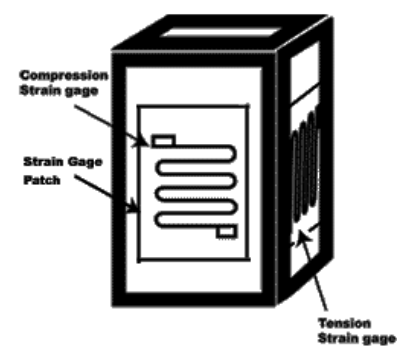

Gambar 2. Load Cell Strain Gauge
Strain Gauge kita sambung dengan konfigurasi Jembatan Wheatstone. Dan kita kalibrasi Amp Meter untuk membaca dalam "Kg" bukan dalam Aampere. Katakanlah kita buat seperti layaknya timbangan. Sebuah timbangan yang kasar dan tidak akurat. Percobaan ini dimaksudkan untuk mengetahui prinsip dasar Load Cell. Load Cell dibuat dalam berbagai bentuk dan konfigurasi. Strain Gauge dipakai untuk mendapatkan gambaran penuh. Rangkaian load cell ditunjukkan pada gambar 3.

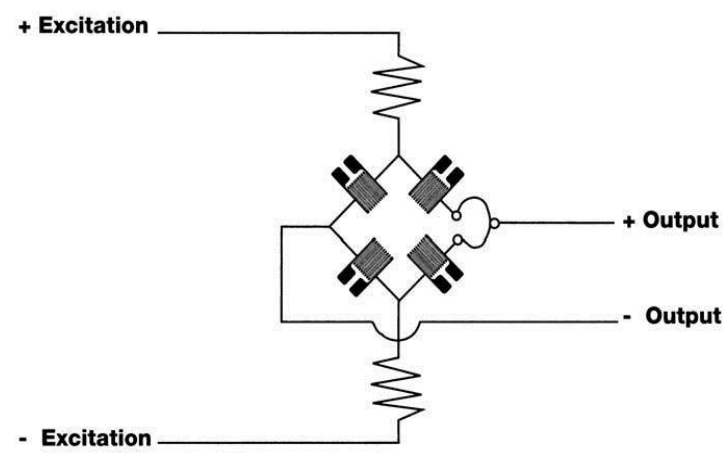

Gambar 3. Rangkaian Load Cell

\section{Strain Gauge}

Starin Gauge tersusun dari kawat yang sangat halus, yang dianyam secara berulang menyerupai kotak dan ditempelkan pada plastic atau kertas sebagai medianya. Kawat yang dipakai dari jenis tembaga lapis nikel berdiameter sekitar seper seribu (0.001) inchi. Kawat itu disusun bolak-balik untuk mengefektifkan panjang kawat sebagai raksi terhadap tekanan/gaya yang mengenainya. Pada ujungnya dipasang terminal. Strain Gauge bisa dibuat sangat kecil, sampai ukuran 1/64 inchi. Untuk membuat Load Cell, Strain Gauge dilekatkan pada logam yang kuat sebagai bagian dari penerima beban (load receptor). Strain Gauge ini disusun sedemikian rupa membentuk Jembatan Wheatstone.

\section{Jembatan Wheatstone (Wheatstone Bridge)}

Rangkaian resistif yang dipakai untuk membuat Load Cell adalah Jembatan Wheatstone. Rangkaian jembatan wheatstone ditunjukkan pada gambar 4.

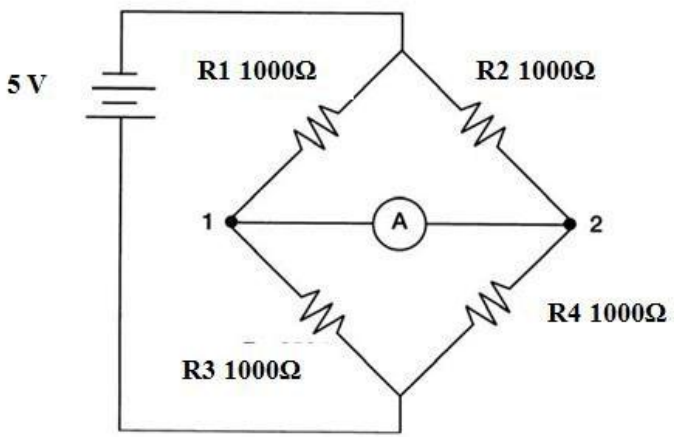

Gambar 4. Rangkaian Jembatan Wheatstone 
Ketika tegangan sumber tersambung ke rangkaian, arus yang mengalir pada cabang R1/R3 sama dengan arus yang mengalir pada R2/R4. Hal ini terjadi karena nilai semua resistor sama. Arus yang terukur pada Ampermeter adalah 0 karena tidak ada beda potensial pada titik 1 dan 2 .

Saat ada beban nilai resistor R1 dan R4 menjadi $1020 \mathrm{ohm}$ dan kurangi nilai resistor R2 dan R3 menjadi 980 ohm karena pada spesifikasi Load Cell $50 \mathrm{Kg}$ yang digunakan adalah $1000 \pm 20 \mathrm{ohm}$.

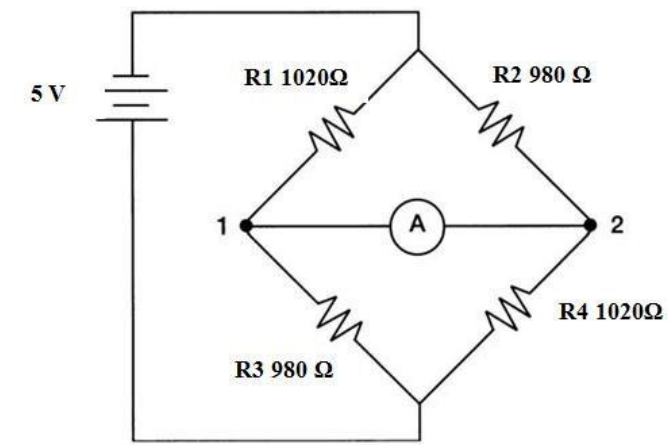

Gambar 5. Jembatan Wheatstone Setelah diberi beban

Seperti terlihat pada gambar 5, rangkaian menjadi tidak seimbang (Unbalanced). Arus yang melalui rangkaian terbagi 3 bagian.

- Bag.1: Dari terminal negatif baterai mengalir melalui R2 dan R4 kembali ke terminal positif baterai.

- Bag.2: Dari terminal negatif baterai mengalir melalui R1 dan R3 kembali ke terminal positif baterai.

- Bag.3: Dari terminal negatif baterai mengalir melalui R2, Ampere Meter, R3 dan kembali ke terminal positif baterai.

Perhatikan, ada arus yang mengalir melalui Ampere meter. Arus yang mengalir terjadi karena ada beda potensial antara titik 1 dan 2. Semakin besar beda potensial di titik tersebut, makin besar pula arus yang terukur di Ampere Meter.

\section{BODY MASS INDEX (BMI) \\ Definisi Body Mass Index}

Body Mass Index (BMI) atau Indeks Quetelet, adalah nilai yang berasal dari massa (berat) dan tinggi individu. BMI didefinisikan sebagai massa tubuh dibagi dengan kuadrat dari tinggi badan, dan secara universal dinyatakan dalam satuan dari $\mathrm{kg} / \mathrm{m}^{2}$, yang dihasilkan dari massa dalam kilogram dan tinggi di meter. BMI juga dapat ditentukan dengan menggunakan table. BMI juga memiliki definisi lain yaitu suatu usaha untuk mengukur jumlah massa jaringan (otot, lemak, dan tulang) dalam individu, dan kemudian mengkategorikan orang itu sebagai kekurangan berat badan, berat badan normal, kelebihan berat badan, atau obesitas berdasarkan nilai tersebut. Namun, ada beberapa perdebatan tentang di mana pada skala BMI garis pemisah antara kategori harus ditempatkan. diterima Umumnya rentang BMI adalah berat badan: di bawah 18,5 , berat badan normal: 18,5-25, kelebihan berat badan: 25 sampai 30, obesitas: lebih 30 .

\section{Penggunaan BMI}

Indeks ini dirancang oleh Adolphe Quetelet 1830-1850 selama waktu yang dia mengembangkan apa yang disebut "fisika sosial". Istilah yang modern "indeks massa tubuh" (BMI) untuk rasio berat tubuh manusia untuk tinggi badan kuadrat berutang nya popularitas sebuah makalah yang diterbitkan dalam edisi 1972 Juli Journal of Penyakit Kronis oleh Ancel Keys. Ini menemukan BMI menjadi proxy terbaik untuk persentase lemak tubuh antara rasio berat tubuh manusia dan tinggi.

Kepentingan dalam indeks yang mengukur lemak tubuh datang dengan meningkatnya obesitas di masyarakat Barat yang makmur. BMI secara eksplisit dikutip oleh Keys yang sesuai untuk studi populasi dan pantas untuk evaluasi individu. Namun demikian, karena kesederhanaan, telah datang untuk digunakan secara luas untuk diagnosis awal. Metrik tambahan, seperti lingkar pinggang, bisa lebih berguna.

Jika pound dan inci yang digunakan, faktor konversi 703 (lb / di $\left.{ }^{2}\right)$ harus diterapkan. Ketika istilah BMI digunakan secara informal, unit biasanya dihilangkan. Rumus Perhitungan BMI dalam kg / $\mathrm{m}^{2}$

$$
\mathrm{BMI}=\frac{\text { massa }}{\text { height }}
$$

Rumus Perhitungan BMI dalam Pound / $\mathrm{Inch}^{2}$

$$
\mathrm{BMI}=\frac{\text { massa }}{\text { height }^{2}} \times 703
$$

BMI berkisar dari underweight untuk obesitas dan umumnya digunakan di kalangan anak-anak dan orang dewasa untuk memprediksi hasil kesehatan. BMI sifat dipengaruhi oleh faktor genetik dan nongenetik, dan menyediakan paradigma untuk memahami dan memperkirakan faktor risiko untuk masalah kesehatan.

BMI memberikan ukuran numerik sederhana dari ketebalan atau ketipisan seseorang, yang memungkinkan para profesional kesehatan untuk membahas masalah berat badan lebih objektif dengan pasien mereka. BMI dirancang untuk digunakan sebagai alat sederhana untuk mengklasifikasi rata menetap (tidak aktif secara fisik) populasi, dengan komposisi tubuh rata-rata. Untuk orang-orang, rekomendasi nilai saat ini adalah sebagai berikut: BMI dari 18,5 hingga 25 mengindikasikan berat badan optimal, BMI lebih rendah dari 18,5 menunjukkan orang tersebut underweight, nomor dari 25 hingga 30 mungkin menunjukkan orang tersebut kelebihan berat badan, dan nomor dari 30 ke atas 
menunjukkan orang tersebut gemuk. Banyak (misalnya pesenam, basket dan sepak bola pemain) tetapi tidak semua (misalnya linemen sepak bola) atlet memiliki otot yang tinggi untuk rasio lemak dan mungkin memiliki BMI yang relatif menyesatkan tinggi persentase lemak tubuh mereka.

\section{CARA KERJA ALAT}

\section{Prinsip Kerja Rangkaian Berat}

Rangkaian Load Cell menerima beban, Strain Gauge R1 dan R4 mengalami gaya tekan. Kawatnya memendek dan diameternya membesar, sehingga nilai resistan R1 dan R4 mengecil. Sebaliknya, Strain Gauge R3 dan R2 mengalami gaya tarik, kawatnya memanjang dan diameternya mengecil sehingga nilai resistan nya membesar. Perubahan nilai resistan ini menyebabkan arus yang melewati R1 dan R4 lebih besar dibanding arus yang lewat pada R3 dan R2. Dan terjadilah beda potensial pada titik output atau signal Load Cell.

Sinyal Outputan Load Cell kemudian di kirimkan masuk chanel + A dan chanel - A yang berada pada module HX711. Di dalam modul HX711 outputan Load Cell yang berupa tegangan tersebut di kuatkan Oleh PGA ( Programable Gain Amplifier ) agar nantinya dapat masuk dan diproses pada Arduino Mega 2560 R3. Setelah tegangan di kuatkan, kemudian diubah menjadi Data digital oleh ADC 24 Bit yang berada pada modul HX711.

Tegangan yang telah diubah menjadi data digital tersebut akan masuk ke dalam Arduino Mega $2560 R 3$ yaitu Data Out (DOUT) HX711 masuk ke Pin 11 Arduino Mega 2560 R3, dan Kemudian Definite SCK (P_SCK) HX711 masuk ke Pin 10 Arduino Mega 2560 R3. Di dalam Arduino Mega $2560 R 3$ di proses menggunakan Bahasa $\mathrm{C}$ dan kemudian ditampilkan pada LCD 20x4 yang merupakan Outputan dari Alat penghitung berat badan.

\section{Flowchart Rangkaian Berat Badan}

Diagram alur sistem (flowchart) ditunjukkan pada gambar 6.

\section{PENGUKURAN DAN PENGUJIAN}

Untuk melaksanakan suatu pengukuran dan pengujian alat, langkah pertama yang dilakukan adalah menyiapkan seluruh peralatan dan komponen yang akan dipasang untuk pengoperasian peralatan tersebut serta alat yang digunakan untuk mengukur dan menguji. Pengukuran dan pengujian hasil rancangan adalah bagian terpenting dari suatu perancangan.

Modul sensor loadcell (HX711) sebagai ADC (analog-to-digital converter), supaya data yang masuk ke Arduino Mega 2560 R3 sudah dalam data digital. Umumnya output loadcell merupakan sinyal analog, maka dari itu perlu dipasang modul HX711 untuk mengubah menjadi data digital dan mempermudah penggunaan dengan Arduino Mega
2560 R3. Data yang didapat dari modul sensor loadcell (HX711) ialah berupa data digital yang selanjutnya dipakai untuk pengkalibrasian timbangan. Data HX711 ditampilkan pada Tabel 1. Untuk hasil pengujian alat ditunjukkan pada tabel 2.

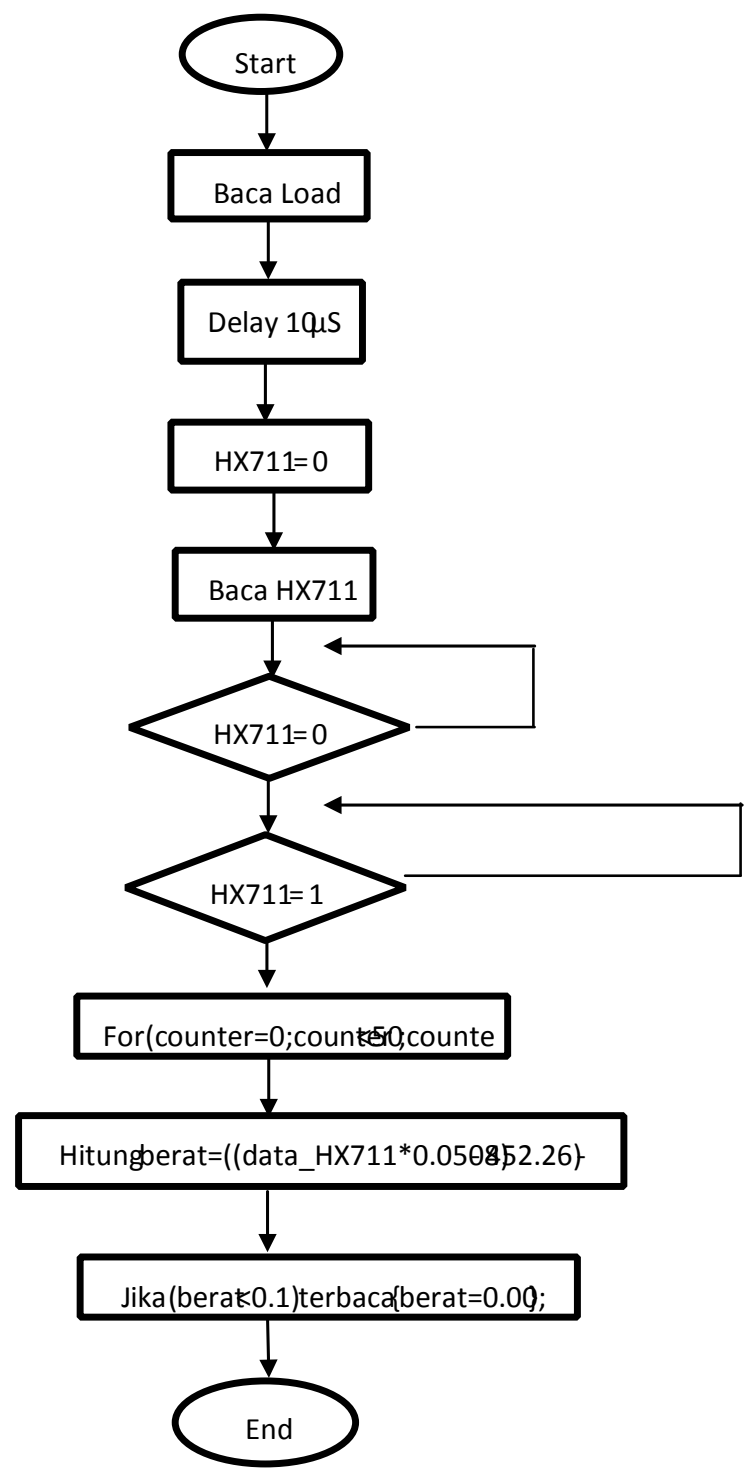

Gambar 6. Diagram alur sistem 
Tabel 1. Data HX711 dan Bandul untuk kalibrasi timbangan

\begin{tabular}{crc}
\hline No. & $\begin{array}{c}\text { Data Digital } \\
\text { HX711 }\end{array}$ & Bandul $(\mathbf{K g})$ \\
\hline 1 & 8906 & 0 \\
2 & 8925 & 1 \\
3 & 8945 & 2 \\
4 & 8965 & 3 \\
5 & 8985 & 4 \\
6 & 9004 & 5 \\
7 & 9024 & 6 \\
8 & 9043 & 7 \\
9 & 9063 & 8 \\
10 & 9083 & 9 \\
11 & 9103 & 10 \\
& & \\
\hline
\end{tabular}

Tabel 2. Berat yang terukur pada alat penghitung berat badan dengan Timbangan Standart serta keterangannya berdasakan BMI

\begin{tabular}{llllll}
\hline No & Nama & $\begin{array}{l}\text { Berat } \\
\text { terukur } \\
(\mathbf{k g})\end{array}$ & $\begin{array}{l}\text { Berat } \\
\text { terukur } \\
\text { pada } \\
\text { alat } \\
(\mathbf{k g})\end{array}$ & $\begin{array}{l}\text { Tinggi } \\
\text { terukur } \\
(\mathbf{c m})\end{array}$ & $\begin{array}{l}\text { Keterangan } \\
\text { di LCD }\end{array}$ \\
& & & 54,55 & 171,5 & $\begin{array}{l}\text { Kurang } \\
\text { ideal }\end{array}$ \\
\hline 1 & Ari & 54,5 & 50,59 & 171,29 & Ideal \\
2 & Dewan & 60,5 & 60,52 & Ideal \\
3 & Taufiq & 55,69 & 56,02 & 165,32 & Obesitas \\
4 & Osep & 85,40 & 85,45 & 172,44 & Obesitas \\
5 & Ricky & 85,8 & 85,04 & 171,31 & Obesitas \\
6 & Faisal & 65,2 & 65,26 & 163,34 & \\
\hline
\end{tabular}

\section{KESIMPULAN}

Berdasarkan percobaan yang telah dilakukan dalam proses pembuatan Alat Pengukur Berat Badan Menggunakan Sensor Load Cell berbasis Arduino Mega 2560 R3, dapat ditarik kesimpulan sebagai berikut :

- Arduino Mega 2560 R3 pada Alat Pengukur Berat badan menggunakan Sensor Load Cell berbasis Arduino Mega 2560 R3 digunakan sebagai Procesornya.

- Modul HX711 digunakan sebagai penguat tegangan yang dihasilkan oleh Load Cell dan digunakan sebagai ADC (Analog Digital Converter) agar dapat diterima oleh Arduino Mega 2560 R3.

- Outputan dari Alat Pengukur Berat badan menggunakan Sensor Load Cell berbasis Arduino Mega 2560 R3 ditampilkan pada LCD 20x4 berupa tampilan Berat badan dalam Kilo $\operatorname{gram}(\mathrm{Kg})$.

- Berdasarkan hasil pengukuran dan pengujian, tingkat ketelitian load cell dari alat pengukur berat badan adalah $99,1 \%-99,91 \%$.

- Secara keseluruhan proses dari Alat pengukur berat badan dan tinggi badan ini dimaksudkan untuk memudahkan user ketika melakukan pengukuran tinggi badan dan berat badan, karena sudah dilengkapi dengan standar BMI serta telah ditampilkan menggunakan layar LCD.

- Alat Pengukur berat badan ini disertai dengan menggunakan standart BMI yang akan menampilkan keterangan kurang ideal, ideal dan obesitas.

\section{DAFTAR PUSTAKA}

1. Fogaswara, Eka. 2013. Prinsip Dasar Kelistrikan dan konversi energy untuk SMK/MAK. Bandung: CV ARMICO.

2. Massimo dkk, Arduino/Genuino Mega 2560. 28 Juli 2015. https://www.arduino.cc/en/Ma in/ArduinoBoardMega2560. Diakses pada 28 Juli 2015.

3. Anonim. Sensor. 5 September 2015. http://id.wikipedia.org/wiki/sensor. Diakses pada 5 September 2015

4. Anonim. HX711 Weight Scale ADC Modul. 6 September 2015. http://www.vcc2gnd.com/ Diakses pada 6 September 2015

5. Arifai, Samsul. Dkk, 2014, Rangkain Catu Daya. http://s3.amazonaws.com/academia.e du.documents/ Diakses pada 24 Agustus 2015

6. Malvino, Prinsip-prinsip Elektronika, Buku satu, Salemba Teknika, hal 66

7. Anonim. Catu daya. 6 September 2015. http://profil.widodoonline.com /Elektronika/komponen/praktik um/teori-dasarcatu-daya.html 